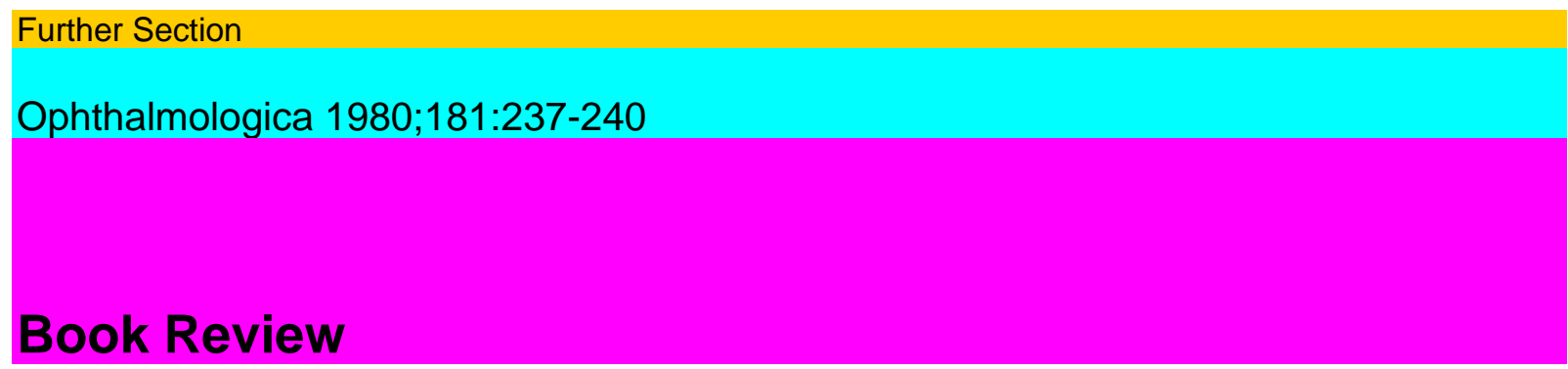

\title{
/. Francois
}

Historia Ophthalmologica Internationally, vol. $1 / 2$

Wayenborgh, Bonn 1979. 216 pp.

Ce petit volume très intéressant publie 10 tra-vaux qui retracent certains aspects de $\Gamma$ histoire de Tophtalmologie de Гantiquité jusqu'à nos jours. On apprend ainsi que les Quinze-Vingts à Paris sont la plus ancienne institution pour aveugles dans le monde; il nous fournit une explication de la cécité de Saint-Paul, donne la liste des timbres émis dans le monde en Thonneur des pionniers de Гophtalmologie. Assez richement illustré, bien présenté, agréable à lire, ce volume est vivement recom-mandé à tous ceux qui sont intéressés par l'histoire de Гophtalmologie.

Cl. Gailloud, Lausanne

Arthur L·im Síew Ming

Practical Ophthalmic Microsurgery

Karger Basel 1979. 96 pp.; SFr. 39.-ISBN 3-8055-3036-6

This small book has 73 pages of well-composed text with 83 clear and appropriate illustrations mostly in colour. The author has a very practical approach to the teaching of microsurgery and his courses have proved of great value to those with no previous experience in operating under the microscope. This has influenced the rapid introduction of microsurgery to the developing countries of the Far East. With other microsurgeons he has established a step-by-step approach based on a detailed analysis of the techniques used.

The enthusiasm which is a feature of this teaching course is carried into this book. The text is full of simple but fundamental points and forms a guide to the basic techniques necessary to gain precision with operating in a magnified field. Many of us have learnt this by experience, but may forget that they are not known by those who are unfamiliar with the operating microscope.

This is a useful book and can be recommended to those who are learning their operating methods. It will help them to avoid mishandling instruments and materials and teach them how the tissues should be handled to improve the results of their surgery.

M. J. Roper-Hall, Birmingham

M. J. Roper-Hall, H. Sautter and E. B. Streiff

(eds.)

Advances in Ophthalmology, vol. 40

Series Editors: M. /. Roper-Hall, H. Sautter and

E. B. Streiff

Karger, Basel 1980

VIII + 224 pp., 55 fig., 51 tab.; sFr. 157.-/

DM 188.-/approx. US- $\$ 94.00$

ISBN 3-8055-3031-5

Auf den ersten 100 Seiten berichtet H. Goldstein, Bethesda, über den gegenwärtigen Stand der Blindheits- und Erblindungsursachenstatistik auf der Welt aufgrund ausgedehnter eigener 
Erfahrung. Die Bedeutung des Problems charakterisiert Verf. mit dem Satz «Without a known etiology there can be no prevention.» In fast alien Teilen der Welt sind die Anstrengungen ungenügend, Methoden und Kriterien der Erfassung uneinheitlich. Das so-ziale Hilfsangebot hat in England und Wales zu einer relativ guten, wenn auch nicht obligatorischen Erfassung geführt. Die Verhältnisse in Kanada sind vergleichbar. Intéressant ist, dass die auf Anre-gung des Verfassers von 16 Staaten der USA, die über ein Blindheitsregister verfügen, durchgeführte Modellstudie ebenfalls nicht zu einem voll befrie-digenden Resultat führen konnte.

Vergleichsmög-lichkeiten zwischen verschiedenene Blindheitsstati-stiken sind nur in sehr beschränktem Masse vor-handen. So bleiben Trendbetrachtungen, wie sie Sorsby 1966 and 1972 für England und Wales in sehr exakter Weise gegeben hat.

Es folgt eine Zusammenstellung der bisher vor-liegenden Statistiken. Verf. beendet seine sowohl 238

Books Reviews $\cdot$ Livres nouveaux $\cdot$ Buchbesprechungen

desillusionierende als auch stimulierende Studie mit einer Reihe von Feststellungen, unter denen einige hervorgehoben seien: 1. Es müssen eine ein-zeitliche Definition der Blindheit und eine Klassi-fikation der Ursachen für Blindheit und Sehschwä-che geschaffen werden. 2. Es muss dafür gesorgt werden, dass diese Massstäbe überall in gleicher Weise angewandt werden. 3. Da alle bisherigen Formen der Berichterstattung (Schätzung, Zensus, Registrierung und statistische Repräsentativstudien) sich als nicht hinreichend genau erwiesen haben, sínd neue Impulse der Ophthalmologen und ihrer wissenschaftlichen Fachgesellschaften erforderlich, wenn der WHO zur Erfüllung einer notwendigen Aufgabe geholfen werden soil (24 Tab., 124 Litera-turangaben). M. Zirm, Innsbruck, gibt dann eine klare und instruktive Darstellung seiner Untersuchungen der Kammerwasserproteine. Die Arbeit zeigt, dass es unter Anwendung moderner Methoden möglich ist, auch kleine Proteinmengen zu bestimmen. Das Kammerwasser für solche Untersuchungen sollte durch Punktion der Vorderkammer und nicht wäh-rend anderer operativer Massnahmen gewonnen werden. Um eine differenzierte und möglichst ex-akte Bestimmung pathologischer Verschiebungen der Proteinkonzentration im Kammerwasser zu er-möglichen, muss man den Vergleich mit einem ge-sunden Auge führen und sollte stets auch die Serumproteine bestimmen. Die Möglichkeit eines Vergleiches durch Punktion des zweiten gesunden Auges eröffnet neue Möglichkeiten der Proteindia-gnostik im Kammerwasser. Für die einfache Routinediagnostik genügt die Bestimmung von Albumin und IgG im Kammerwasser. Die $40 \mu \backslash$ für diese Untersuchungen sind harmlos und schnell zu gewinnen. Die Bildung eines Albumin-IgG-Quotienten erlaubt Rückschlüs-se auf allgemein-entzündliche Veränderung bzw. ihren Ausschluss oder einen Hinweis auf eine lo-kale Immunreaktion mit relativem Anstieg des Im-munoglobulins.

Das vom Verf. im 5. Kapitel seiner Studie vor-gestellte Protein-Filtrationsmodell kann hier im einzelnen nicht referiert werden. Die schöne, gut illustrierte Arbeit bedeutet eine Abrundung unse-rer bisherigen Kenntnisse und sollte auch werden-den Ophthalmologen in fortgeschrittenem Ausbil-dungsstadium empfohlen werden (41 Abb., 24 Tab., 134 Literaturangaben).

Auf den letzten 50 Seiten gibt die Arbeitsgruppe 39 des National Research Council einen ersten Benefit mit Standardisierungsvorschlägen im Bereich der Gesichtsfeldprüfung, die alle Parameter von seiten der Apparatur und des Patienten zu berück-sichtigen versuchen. Die Angaben beziehen sich auf den Tangentenschirm (Graefe), das Goldmann- und das HarmsAulhorn-Perimeter. Die Probleme der Automation werden kurz angesprochen (14 Abb., 3 Tab., 74 Literaturangaben). 
Hellmut Neubauer, Köln

Fordyce Johnson

Allergy: Including IgE in Diagnosis and

Treatment

Year Book Medical Publishers, London 1979 IX+ 294 pp.; US\$37.75 ISBN 0-8151-4903-4

Under the editorship of Prof. Fordyce Johnson this work by many authors includes a theoretical introduction to immunology and to the study of IgE. Tests for measuring IgE are reviewed, emphasis being on the radioimmunosorbent (RIST) and radioallergosorbent (RAST) tests which can distinguish between total $\mathrm{IgE}$ and the specific variety. Reagents for these tests are available from special firms mentioned and it seems that in the USA these tests may be carried out in the physician's 'office'. Some other countries, however, require all radioisotope work to be carried out in approved centres only. According to the work reviewed, these tests are costly, subject to technical difficulties and a range of error may require repetition when used in monitoring immunotherapy for allergy. Non-radioactive tests and methods are still in use, ranging from skin testing to the more recent im-munoperoxidase test and the enzyme-linked im-munosorbent assay (ELISA).

Other chapters are devoted to food allergy and provocative food testing and to inhalational allergens. Therapeutic measures are discussed and in the chapter on drug therapy the only ophthalmic reference encountered is a paragraph on the value of cromolyn sodium in the allergic conjunctivitis associated with acute pollinosis.

Book Reviews $\cdot$ Livres nouveaux $\cdot$ Buchbesprechungen 239

The view is expressed elsewhere that better results have been obtained in both allergic rhinitis and asthma by giving immunotherapy with only RAST-positive allergens, as opposed to skin testing positive allergens. This appears as a significant contribution to the treatment of allergy if, as the authors of the relevant chapter rightly mention, these results can be confirmed by additional prospective studies.

The work is mainly by immunologists, allergologists, and otoralyngologists. The ophthalmologist reader may not find very much of practical value in his specialty but may be interested to know how others deal with problems of general or other localised allergies. The index bears some inaccuracies in the page numbering. A self-evaluation quiz is given at the end of each chapter and a review of current publications is included.

D. R. Barry, Birmingham

A. Yeadon and D. Gray son

Living with Impaired Vision: An Introduction

American Foundation for the Blind New York, 197977 pp.; US\$7.00 ISBN 0-89128-088-X This is an excellent little book which has been produced for the guidance of anybody who comes into contact with the visually handicapped. It is authoritative and sound and has many useful hints to make the lives of the visually handicapped more acceptable. The book is generously illustrated and is brimming over with common sense. It is most warmly recommended.

A. Steele, London

E. M. Siegel

Print Materials on Visual Impairment

M.C. Migel Memorial Library Acquisitions List 
(April 1978 - April 1979)

American Foundation for the Blind,

New York 1979

80 pp.; US\$6.00

ISBN 0-89128-095-2

The M. C. Migel-Memorial Library at the American Foundation of the Blind was established in 1926 to provide scholars, researchers, practitioners, and others with a centralized source of printed material relating to all aspects of blindness and visual impairment and now contains over 35,000 titles. This booklet is a bibliography, comprising a compilation of materials added to the collection from April 1978 to April 1979. It contains a great number of new titles dealing with all aspects of blindness and visual impairment and updates the M. C. Migel library catalogue. All those who are faced with the difficult problem of locating specific literature related to blindness or visual impairment will greatly profit from being able to consult this compilation.

F. Fankhauser

H.-J. Merté

Augenärztliche Fortbildung: Jahreskurse für die

praktische Augenheilkunde, vol. 6, Teil 1 und 2

Urban \& Schwarzenberg, München 1980

270 pp.; DM40.- pro Teilband

ISBN 3-541-09062-6

Die beiden Bände enthalten Beiträge zu den Kapiteln «Erkrankungen der Orbita und ihres Inhaltes», «Physiologie und Pathologie des Bewe-gungsapparates und des binokularen Sehaktes», «Neuro-Ophthalmologíe», «Refraktion und Sehhil-fen» sowie aus der Ergophthalmologie.

Im Teil 1 referiert zunächst Griiner in seinem Beitrag «Erkrankungen der Orbita» unter Berücksichtigung der Veröffentlichungen der letzten Jahre über neue Gesichtspunkte in der Diagnostik und Therapie der Orbitaerkrankungen. Zur Untersu-chung dient einmal die Ultraschallmethode. Fer-ner kommt der röntgenologischen Diagnostik und der Computer-Tomographie eine erhebliche Bedeu-tung zu, während Szintigraphie undThermographie nur als zusätzliche Hilfsmittel verwendet werden sollten. Hinsichtlich des therapeutischen Vorgehens bei Orbitabodenfrakturen spricht vieles dafür, dass die Erstversorgung vom Ophthalmologen durchge-führt werden sollte. Bei der Diagnostik der endo-krinen Orbitopathie ist nach wie vor die Bestim-

240

Book Reviews Livres nouveaux Buchbesprechungen

mung der Hormon-Jod-Phase des 2-Phasen-Radio-jod-Stoffwechsel-Studiums wesentlich. In einem weiteren Beitrag berichtet Burk über die Ergebnisse der operativen Behandlung der Trichiasis, des trachomatösen Narbenentropiums und der Blepharophimose mit kongenitaler Ptosis. Bei den Erkrankungen der Tränenorgane gilt nach wie vor dem Syndrom des trockenen Auges ein beson-deres Interesse, wobei Hyposekretion, Muzinman-gel der Bindehaut und Lipidmangel ausgeschlossen werden müssen. Bei den Tränenabflussstörungen wendet sich das Interesse heute eher den Verschlüs-sen des Tränenpünktchens bzw. der Canaliculi zu, dienichtnur durch Verletzung, sondern auch durch virale Infekte oder sogar iatrogen verursacht sein können. Des weiteren folgt eine Arbeit von Boeder und Burde über die Verschiebung der Sehrichtungsant-wort. Die klassische Theorie, nach der die ange-borene Korrespondenz aufgehoben und durch an-omale Verkuppelungen ersetzt werden kann, wird verworfen. Die 
Verfasser glauben, dass die normale Korrespondenz nach wie vor bestehen bleibt und dass binokulares Einfachsehen bei konkomitieren-dem Schielen durch eine Antwortverschiebung im abgewichenen Auge erreicht wird.

Frledburg referiert über «Suppression und an-omale Korrespondenz - neurophysiologische Modellvorstellungen». Zwei Hypothesen werden auf ihre Wahrscheinlichkeit hin verglichen: 1.

Anomale Korrespondenz beruht auf der totalen Zerstörung der normalen Binokularbeziehungen und dem völlig neuen Aufbau eines anomalen binokularen Mechanismus. 2. Anomale Korrespondenz und an-omales Binokularsehen funktionieren unterVerwen-dung des normal angelegten Binokularmechanis-mus einschliesslich seiner kortikalen Verschaltun-gen. In einer redaktionellen Notiz geht Bruckner auf die Amblyopiebehandlung mit weichen Okklusions-linsen ein. Diese schwarz eingefärbten Kontakt-linsen werden morgens eingesetzt und abends wie-der herausgenommen, sind also keine Langzeitlin-sen.

Bezüglich der Ergophthalmologie berichtet Merté über Untersuchungen für die Arbeit am Datensichtgerät sowie über die Empfehlung der DOG zurDurchführung von augenärztlichen Untersuchungen des dort beschäftígten Personenkreises. Zusätzlich referiert Conrads über die Normen für

Bildschirm-Arbeitsplätze, Aufgaben und Einsatz von Bildschirmgeräten und die Anforderungen, die an die Bedienung im einzelnen zu stellen sind.

$7>$;72enthält zunächst ein Referat von Bruckner über die Katarakt im Kindesalter. Es wird auf die besondere Bedeutung einer frühzeitigen Operation hingewiesen und auf die Problematik der Implantation einer Kunststofflinse eingegangen.

Das Referat von Binkhorst, Graeves, Kats und Bermingham beschäftigt sich mit der Behandlung traumatischer Katarakte bei Kindern mit iridokap-sulärer Linseneinpflanzung. Auf der Basis der ins-gesamt vielversprechenden Möglichkeiten der vi-suellen Rehabilitation werden Richtlinien für best-mögliche Behandlung von Augenverletzungen im Kindesalter formuliert.

Ein weiterer Beitrag von Kommereil geht auf die Sekundärveränderungen bei

Augenmuskellähmun-gen ein. Hierbei ist auf entstehende Kontrakturen am nichtparetischen Partnerauge zu achten, wenn dieses dauernd zur Fixation benützt wird. Wesentlich ist die Anpassung der Blick- und Körper-motorik.

Huber behandelt dann das Okulomotoriusneu-rinom, das bei mehrfacher Fallbeobachtung präoperativ niemals diagnostiziert wurde.

Ein weiterer Beitrag von Huber befasst sich mit Diagnose und Differentialdiagnose der Stauungspapille. Das breite Spektrum von Erkrankungen, die als Ursache einer entsprechenden Veränderung anzusehen sind, sowie die differential-diagnostisch erforderlichen Untersuchungen werden ausführlich dargestellt.

Abschliessend berichtet Sachsenweger über die Rolle der Fusion bei der Beziehung zwischen Re-fraktion, Akkommodation und Konvergenz. Sie be-deuten für die Fusion zusätzliche Störfaktoren und Insuffizienzmöglichkeiten. Asthenopien haben eine bemerkenswert unterschiedliche Beziehung zu die-sen Faktoren, weshalb ein entsprechendes Training sehr vorteilhaft sein kann. Die Fixationsdisparität ist im Unterschied zum Mikrostrabismus ein starker Impuls für die Fusionierung, erschwerte oder mangelhafte Fusion dagegen die häufigste, aber variable, Ursache des Begleitschielens.

I. Im ganzen besitzen die Beiträge in beiden Tei-len dieser Ausgabe einen durchaus lesenswerten Fortbildungsgehalt.

H.Sautter

Hamburg 
